\title{
Optimization of the Actuarial Model of Defined Contribution Pension Plan
}

\author{
Yan Li, ${ }^{1}$ Yuchen Huang, ${ }^{1}$ and Yancong Zhou ${ }^{2}$ \\ ${ }^{1}$ School of Insurance and Economics, University of International Business and Economics, Beijing 100029, China \\ ${ }^{2}$ School of Information Engineering, Tianjin University of Commerce, Tianjin 300134, China
}

Correspondence should be addressed to Yancong Zhou; zycong78@126.com

Received 17 March 2014; Accepted 20 May 2014; Published 12 June 2014

Academic Editor: Xiaochen Sun

Copyright (C) 2014 Yan Li et al. This is an open access article distributed under the Creative Commons Attribution License, which permits unrestricted use, distribution, and reproduction in any medium, provided the original work is properly cited.

The paper focuses on the actuarial models of defined contribution pension plan. Through assumptions and calculations, the expected replacement ratios of three different defined contribution pension plans are compared. Specially, more significant considerable factors are put forward in the further cost and risk analyses. In order to get an assessment of current status, the paper finds a relationship between the replacement ratio and the pension investment rate using econometrics method. Based on an appropriate investment rate of $6 \%$, an expected replacement ratio of $20 \%$ is reached.

\section{Introduction}

China's current social security system was established July 1, 1997, which was updated in 2005. When it comes to supplemental pension plan, it is used as a way to provide more benefits over the social security system which is discussed in [1]. The supplemental pension plan functions in the following two fields. The first one is to complement the insufficient social pension insurance treatment. The second one is to stabilize employees and keep enterprises employees focus on their work. Retirement plans of supplemental pension are divided into defined benefit and defined contribution plans. In a defined benefit plan, the funding is intended to ensure that sufficient pension funds will be available to pay promised benefits. In a defined contribution plan in [2], the benefit received equals the contributions to the plan, adjusted for possible investment.

Though China supplemental pension plan has been carried out commonly, there are some large troubles. In 2011, the replacement ratio of whole pension plan was only $42.9 \%$. When reaching $80 \%$, we will judge that the protection of retirement employees is adequate. Some researchers expect that the average replacement ratio of developed supplemental pension system will reach $20 \%$, which is appropriate.

Foreign researches on supplemental pension plan are wide. Leime and Seling regarded supplemental pension plan as a deferred survival annuity. Within the prescribed period of time, the insured is to pay a fee every year to the insurer, which will be maintained until the insured retires. If the insured is still survival at retirement, the insured can achieve a certain amount from the insurer each year until death. The actuarial present value of the insured's contribution equals the actuarial present value of the insurer's future payments.

In this paper, application is given priority. We try to compare different types of defined contribution pension plans and test their effectiveness under the consideration of costs and risks. All of these try to give some explanations of the actual application of the pension plan and provide some suggestions for China pension market.

\section{Data and Assumption}

The sample data used in our analyses is contained in Table 1, simply the basic information of employees, which comes from a certain governmental institution. The institution has 15 executive management level employees.

The China life insurance industry experience life table (2000-2003) is also used in the spreadsheet model.

As discussed by Bills and Lyon, the following assumptions are also used in the model in [3]. 


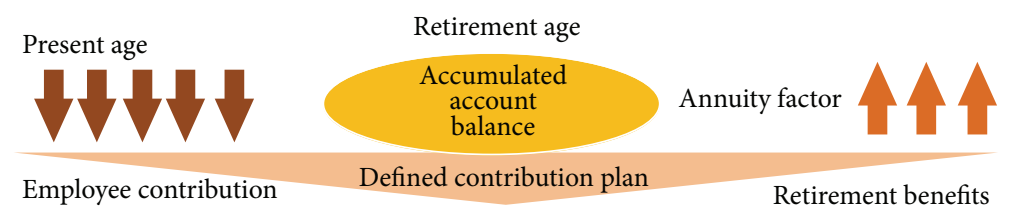

Figure 1: Defined Contribution Plan Mechanisms. Resource: Model Calculation Analysis.

TABLE 1: Sample employees information.

\begin{tabular}{lccccc}
\hline ID & Name & Gender & Present age & Entry age & $\begin{array}{c}\text { Present salary } \\
\text { per month }\end{array}$ \\
\hline 1 & A & F & 54 & 46 & 29190 \\
2 & B & M & 47 & 45 & 39591 \\
3 & C & M & 46 & 32 & 65100 \\
4 & D & M & 44 & 32 & 29190 \\
5 & E & F & 42 & 34 & 26625 \\
6 & F & F & 46 & 38 & 23000 \\
7 & G & M & 40 & 31 & 39591 \\
8 & H & F & 36 & 26 & 15954 \\
9 & I & M & 40 & 28 & 27800 \\
10 & J & F & 50 & 36 & 5023 \\
11 & K & M & 44 & 37 & 27957 \\
12 & L & F & 50 & 32 & 4556 \\
13 & M & F & 37 & 30 & 27957 \\
14 & N & M & 49 & 39 & 26625 \\
15 & O & F & 47 & 30 & 16751 \\
\hline
\end{tabular}

Resource: government institution sample data.

TABLE 2: Assumption of salary increase rate.

\begin{tabular}{lc}
\hline Future service years & Salary increase rate \\
\hline $0<$ Year $\leq 5$ & $10 \%$ \\
$5<$ Year $\leq 10$ & $8 \%$ \\
$10<$ Year $\leq 15$ & $6 \%$ \\
Year $>15$ & $5 \%$ \\
\hline
\end{tabular}

Resource: spreadsheet model assumption.

(i) In this paper, all of the pension plans are based on mechanism of defined contribution model.

(ii) The present time is 7/1/2013.

(iii) The data of annuity factor in life table is used for calculations.

(iv) The retirement age for male is 60 , for female 55 .

(v) The retirement benefits are paid until death, with a discount rate of $80 \%$. This assumption presents the possibility of deducting benefits and potential risks.

(vi) The fixed rate of monthly salary contribution is $10 \%$, which is a general level.

(vii) The future salary increase rate per year is related to future services year as Table 2 shows. (viii) The interest rate is $5 \%$ per year, $0.41 \%$ per month.

The risk-free rate varies from $5 \%$ to $6 \%$. The minimum one, $5 \%$, is first chosen in the model analysis. This assumption is performed in the following sensitivity analysis.

(ix) The Investment return rate is $5 \%$.

The investment of China supplemental pension individual accounts has many limits. The percentage of fixed interest products (mainly the Treasury bond) must be greater than $50 \%$. The percentage of equity products must be less than $30 \%$. In particular, stocks must be less than $20 \%$. In practice, the expected invested return is $5.5 \%$. We assume that it is $5 \%$.

\section{Model Description (The Spreadsheet Model Is Contained in Table 3)}

The work is completed using a basic "defined contribution plan" spreadsheet model. The relative symbols are contained in Table 4. Three different defined contribution plans are tested. The analysis is performed using a spreadsheet model, entering the established assumptions as parameters into the model. Using the Input fields, various parameters related to the employees' information are entered. The model is used to calculate replacement ratios at retirement age for an individual employee under the conditions of different plans.

Calculation Original Mechanism. See Figure 1.

Symbol Description. See Table 4.

Calculation Basic Formula.

(i) Original defined contribution plan: $\mathrm{EC} * \mathrm{Sn}=\mathrm{RB} *$ $\mathrm{AF} ; \mathrm{RR}=\mathrm{RB} / S$.

(ii) Modified defined contribution plan: IA $+\mathrm{EC} * \mathrm{Sn}=$ $\mathrm{RB} * \mathrm{AF} ; \mathrm{RR}=\mathrm{RB} / S$.

(iii) Hybrid plan: $\mathrm{EC} * \mathrm{Sn}=\mathrm{RB} * \mathrm{AF}$; $\mathrm{RR}=\mathrm{RB} / S(\mathrm{RB} \geq$ $\mathrm{PB}) ; \mathrm{RR}=\mathrm{PB} / S(\mathrm{RB}<\mathrm{PB})$.

\section{Analysis}

4.1. Sample Human Demographic Analysis. Human demographic information is an important external factor for a pension plan. We do some analyses on the data of 15 executive management level employees and show some findings and graphics below. 
TABLE 3: Summary.

\begin{tabular}{lccccccccc}
\hline ID & Gender & $\begin{array}{c}\text { Present } \\
\text { age }\end{array}$ & $\begin{array}{c}\text { Entry } \\
\text { age }\end{array}$ & $\begin{array}{c}\text { Present } \\
\text { salary } \\
\text { per month }\end{array}$ & $\begin{array}{c}\text { Original } \\
\text { DC }\end{array}$ & $\begin{array}{c}\text { Modified } \\
\text { DC }\end{array}$ & $\begin{array}{c}\text { Hybrid } \\
\text { plan }\end{array}$ & $\begin{array}{c}\text { Modified } \\
\text { cost }\end{array}$ & $\begin{array}{c}\text { Hybrid } \\
\text { cost }\end{array}$ \\
\hline 1 & F & 54 & 46 & 29,190 & $0.79 \%$ & $5.72 \%$ & $24.92 \%$ & $342,531.00$ & $1,409,256.00$ \\
2 & M & 47 & 45 & 39,591 & $8.02 \%$ & $9.16 \%$ & $9.47 \%$ & $99,636.00$ & $192,012.00$ \\
3 & M & 46 & 32 & 65,100 & $8.57 \%$ & $19.40 \%$ & $8.57 \%$ & $1,569,581.00$ & 0.00 \\
4 & M & 44 & 32 & 29,190 & $10.39 \%$ & $20.43 \%$ & $12.56 \%$ & $571,364.00$ & $215,232.00$ \\
5 & F & 42 & 34 & 26,625 & $6.87 \%$ & $11.43 \%$ & $14.09 \%$ & $312,432.00$ & $746,028.00$ \\
6 & F & 46 & 38 & 23,000 & $4.56 \%$ & $8.56 \%$ & $17.40 \%$ & $269,894.00$ & $1,074,372.00$ \\
7 & M & 40 & 31 & 39,591 & $12.91 \%$ & $19.86 \%$ & $12.91 \%$ & $536,557.00$ & 0.00 \\
8 & F & 36 & 26 & 15,954 & $10.52 \%$ & $17.32 \%$ & $19.84 \%$ & $246,680.00$ & $683,952.00$ \\
9 & M & 40 & 28 & 27,800 & $12.91 \%$ & $22.95 \%$ & $12.91 \%$ & $544,157.00$ & 0.00 \\
10 & F & 50 & 36 & 5,023 & $2.68 \%$ & $11.08 \%$ & $98.89 \%$ & $121,106.00$ & $1,416,276.00$ \\
11 & M & 44 & 37 & 27,957 & $10.39 \%$ & $15.52 \%$ & $13.11 \%$ & $279,672.00$ & $258,828.00$ \\
12 & F & 50 & 32 & 4,556 & $2.68 \%$ & $14.74 \%$ & $109.03 \%$ & $157,799.00$ & $1,419,936.00$ \\
13 & F & 37 & 30 & 27,957 & $9.98 \%$ & $14.38 \%$ & $11.89 \%$ & $279,672.00$ & $233,820.00$ \\
14 & M & 49 & 39 & 26,625 & $6.89 \%$ & $14.04 \%$ & $15.83 \%$ & $411,674.00$ & $704,244.00$ \\
15 & F & 47 & 30 & 16,751 & $4.13 \%$ & $15.30 \%$ & $25.80 \%$ & $532,804.00$ & $1,222,500.00$ \\
\hline
\end{tabular}

TABLE 4: Symbol determination.

\begin{tabular}{lc}
\hline Employer contribution per month & EC \\
Annuity factor (life table) & AF \\
Years before retirement & $N$ \\
Replacement ratio & RR \\
Initial account amounts & IA \\
Accumulated account balance & AA \\
Retirement benefits per month & RB \\
Accumulated value of annuity & Sn \\
Salary per month & $S$ \\
Promised benefits & PB
\end{tabular}

Resource: model symbol determination.

(i) The average age of employees is high, 44.80. For men, the average age is 44.28; for women, the average age is 45.25 . As the women will get retired 5 years earlier than men, the pressure of pension plan for women is greater.

(ii) All employees are under the same social security system, which I don't consider in my analyses. The defined contribution pension plan is used for supplemental pension plan.

(iii) Some employees have high age with shorter future service years. 5 employees will retire in 10 years. Their salary is on the low side, compared to the younger. The monthly salary of two employees aged 50 is less than 5,500. The future accumulated years for individual accounts may not be enough.

(iv) The salary of the employees who have a longer past services year (more than 10 years) is more different, 65,100 as the maximum and 4,556 as the minimum.
The salary for shorter service years' employees is more stable.

\subsection{Defined Contribution Pension Plan}

4.2.1. Original Defined Contribution Pension Plan. A defined contribution plan will provide many details to determine the annual contribution made by employer on behalf of each employee as well as any relevant regulations. In analysis, contribution rate is assumed. The formula determines how much an employee receives from each plan.

Based on the data, assumptions, and model above, the replacement ratio of all employees are calculated under original defined contribution plan. First, we calculate the expected accumulated individual account at retirement age for each employee. Then, with the annuity factor provided by life table, we estimate the future retirement benefits. Finally, the replacement ratio is obtained.

The results are summarized in Table 5. The results vary from $0.79 \%$ (the oldest one) to $12.91 \%$ (the youngest one). We can almost see that "the younger, the better". The average replacement ratio is $7.49 \%$, far less than the average replacement ratio of China, $20 \%$. In fact, no employees will have a reasonable replacement ratio, over $20 \%$.

The accumulated period (future service years) of individual accounts is adequate, certainly including the sample company. The pure pension plan, defined contribution, can't provide appropriate retirement benefits coverage.

4.2.2. Modified Defined Contribution Pension Plan. According to the results in Table 5, we can conclude that the supplemental retirement compensation, simply the defined contribution pension plan, is not enough for employees and more compensation expenses are necessary. Some solutions are proposed. 
TABLE 5: Replacement ratio for original defined contribution pension plan.

\begin{tabular}{lccccc}
\hline ID Gender & $\begin{array}{c}\text { Present } \\
\text { age }\end{array}$ & $\begin{array}{c}\text { Entry } \\
\text { age }\end{array}$ & $\begin{array}{c}\text { Present salary } \\
\text { per month }\end{array}$ & $\begin{array}{c}\text { Original } \\
\text { replacement } \\
\text { ratio }\end{array}$ \\
\hline 1 & $\mathrm{~F}$ & 54 & 46 & $29,190.00$ & $0.79 \%$ \\
2 & $\mathrm{M}$ & 47 & 45 & $39,591.00$ & $8.02 \%$ \\
3 & $\mathrm{M}$ & 46 & 32 & $65,100.00$ & $8.57 \%$ \\
4 & $\mathrm{M}$ & 44 & 32 & $29,190.00$ & $10.39 \%$ \\
5 & $\mathrm{~F}$ & 42 & 34 & $26,625.00$ & $6.87 \%$ \\
6 & $\mathrm{~F}$ & 46 & 38 & $23,000.00$ & $4.56 \%$ \\
7 & $\mathrm{M}$ & 40 & 31 & $39,591.00$ & $12.91 \%$ \\
8 & $\mathrm{~F}$ & 36 & 26 & $15,954.00$ & $10.52 \%$ \\
9 & $\mathrm{M}$ & 40 & 28 & $27,800.00$ & $12.91 \%$ \\
10 & $\mathrm{~F}$ & 50 & 36 & $5,023.00$ & $2.68 \%$ \\
11 & $\mathrm{M}$ & 44 & 37 & $27,957.00$ & $10.39 \%$ \\
12 & $\mathrm{~F}$ & 50 & 32 & $4,556.00$ & $2.68 \%$ \\
13 & $\mathrm{~F}$ & 37 & 30 & $27,957.00$ & $9.98 \%$ \\
14 & $\mathrm{M}$ & 49 & 39 & $26,625.00$ & $6.89 \%$ \\
15 & $\mathrm{~F}$ & 47 & 30 & $16,751.00$ & $4.13 \%$ \\
\hline & & & & $7.49 \%$ \\
\hline
\end{tabular}

Resource: model calculation results.

Considering the past services years for each employee, there should be an initial accumulated individual account. This amount will also be invested until retirement. We assume that the past salary is the present salary provided and the contribution rate is still fixed $10 \%$. Therefore, the accumulated individual account at retirement age, the expected replacement ratio, will increase. The results are summarized in Table 6.

From the results, we can see that the compensation expense is a huge expenditure for employer. Some employees have served for long years. The modified defined contribution plan may be easy to accept. The initial account is a big amount.

However, the replacement ratio is increased but it is still unexpected, almost still less than $20 \%$, possibly because of the future increased salary and the inadequate investment return. The average replacement ratio of this plan is $14.66 \%$, with an average increase of $7.17 \%$. Employees 4, 7, and 9 may be satisfied, as their length of service is long and their salary is not too high. With a relatively low salary, the pressure of pension benefit will be much smaller.

4.2.3. Hybrid Pension Plan. The hybrid pension plan will guarantee the profits more effectively. In this plan, the benefit formula looks like a defined contribution plan, but the plan is really a defined benefit plan. The plan administrator keeps track of the monthly contributions into the account and guarantees a crediting pension level. If the employees earn less, the plan must fund the shortfall.

Our sample company is a governmental one, reasonably with better pension care. As some employees' estimated monthly pension is not enough, the following hybrid pension plan is more direct. We assume that every employee should
TABLE 6: Replacement ratio for modified defined contribution pension plan.

\begin{tabular}{lccccc}
\hline ID & Gender & $\begin{array}{c}\text { Present } \\
\text { age }\end{array}$ & $\begin{array}{c}\text { Entry } \\
\text { age }\end{array}$ & $\begin{array}{c}\text { Present salary } \\
\text { per month }\end{array}$ & $\begin{array}{c}\text { Replacement } \\
\text { ratio }\end{array}$ \\
\hline 1 & $\mathrm{~F}$ & 54 & 46 & $29,190.00$ & $5.72 \%$ \\
2 & $\mathrm{M}$ & 47 & 45 & $39,591.00$ & $9.16 \%$ \\
3 & $\mathrm{M}$ & 46 & 32 & $65,100.00$ & $19.40 \%$ \\
4 & $\mathrm{M}$ & 44 & 32 & $29,190.00$ & $20.43 \%$ \\
5 & $\mathrm{~F}$ & 42 & 34 & $26,625.00$ & $11.43 \%$ \\
6 & $\mathrm{~F}$ & 46 & 38 & $23,000.00$ & $8.56 \%$ \\
7 & $\mathrm{M}$ & 40 & 31 & $39,591.00$ & $19.86 \%$ \\
8 & $\mathrm{~F}$ & 36 & 26 & $15,954.00$ & $17.32 \%$ \\
9 & $\mathrm{M}$ & 40 & 28 & $27,800.00$ & $22.95 \%$ \\
10 & $\mathrm{~F}$ & 50 & 36 & $5,023.00$ & $11.08 \%$ \\
11 & $\mathrm{M}$ & 44 & 37 & $27,957.00$ & $15.52 \%$ \\
12 & $\mathrm{~F}$ & 50 & 32 & $4,556.00$ & $14.74 \%$ \\
13 & $\mathrm{~F}$ & 37 & 30 & $27,957.00$ & $14.38 \%$ \\
14 & $\mathrm{M}$ & 49 & 39 & $26,625.00$ & $14.04 \%$ \\
15 & $\mathrm{~F}$ & 47 & 30 & $16,751.00$ & $15.30 \%$ \\
\hline
\end{tabular}

Resource: model calculation results.

TABLE 7: Replacement ratio for hybrid pension plan.

\begin{tabular}{lccccc}
\hline ID & Gender & $\begin{array}{c}\text { Present } \\
\text { age }\end{array}$ & $\begin{array}{c}\text { Entry } \\
\text { age }\end{array}$ & $\begin{array}{c}\text { Present salary } \\
\text { per month }\end{array}$ & $\begin{array}{c}\text { Replacement } \\
\text { ratio }\end{array}$ \\
\hline 1 & F & 54 & 46 & $29,190.00$ & $24.92 \%$ \\
2 & M & 47 & 45 & $39,591.00$ & $9.47 \%$ \\
3 & M & 46 & 32 & $65,100.00$ & $8.57 \%$ \\
4 & M & 44 & 32 & $29,190.00$ & $12.56 \%$ \\
5 & F & 42 & 34 & $26,625.00$ & $14.09 \%$ \\
6 & F & 46 & 38 & $23,000.00$ & $17.40 \%$ \\
7 & M & 40 & 31 & $39,591.00$ & $12.91 \%$ \\
8 & F & 36 & 26 & $15,954.00$ & $19.84 \%$ \\
9 & M & 40 & 28 & $27,800.00$ & $12.91 \%$ \\
10 & F & 50 & 36 & $5,023.00$ & $98.89 \%$ \\
11 & M & 44 & 37 & $27,957.00$ & $13.11 \%$ \\
12 & F & 50 & 32 & $4,556.00$ & $109.03 \%$ \\
13 & F & 37 & 30 & $27,957.00$ & $11.89 \%$ \\
14 & M & 49 & 39 & $26,625.00$ & $15.83 \%$ \\
15 & F & 47 & 30 & $16,751.00$ & $25.80 \%$ \\
\hline & & & Average & & $27.15 \%$ \\
\hline
\end{tabular}

Resource: model calculation results.

have a credit monthly pension of 8,000 . Therefore, it is necessary to replenish future pension for those with less than certain 8,000 . Thus the expected replacement ratio for certain employees will increase. The results of hybrid pension plan are summarized in Table 7.

The hybrid pension is better than the modified pension. The 8,000 guarantee per month is directly added to the future 


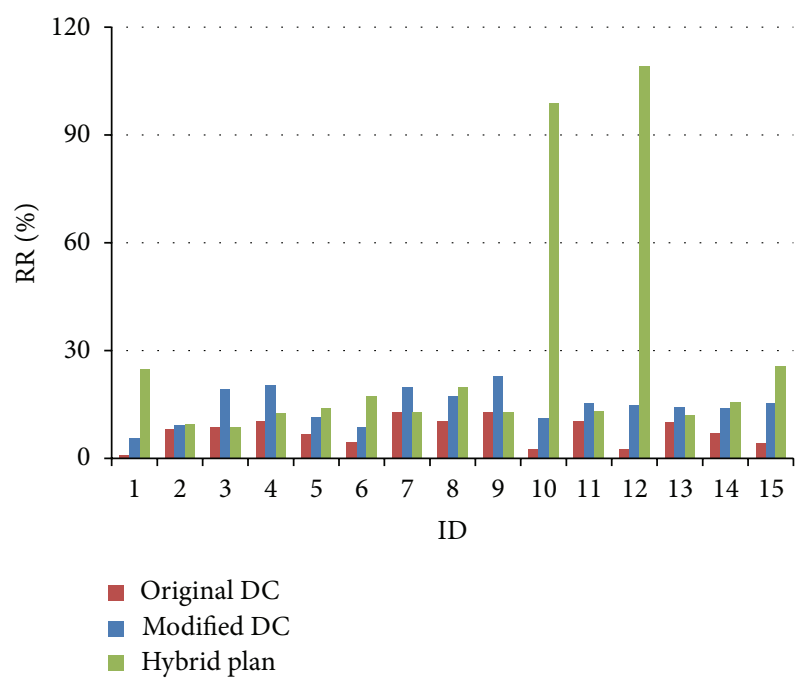

Figure 2: The replacement ratios of three defined contribution pension plans. Resource: spreadsheet model calculation results.

retirement benefits, more effectively. The average replacement ratio of hybrid pension plan is $27.15 \%$, with an average increase of $19.66 \%$.

The minimum replacement ratio is $8.57 \%$, with no change, due to his maximum salary. The replacement ratio of employees 10 and 12 even exceed $95 \%$ because of their relatively low salary. Just due to the low salary, their initial account in modified defined contribution plan is small, ineffectively.

Up to now, three defined contribution pension plans have been analyzed above. The comparison graph is shown in Figure 2. It is obvious that, the replacement ratio is improved under the two improved plans, especially the hybrid plan.

4.3. Cost Analysis. The modified defined contribution pension plan and the hybrid pension plan can be regarded as improved defined contribution plan. There is an estimated compensation expense for this improvement.

In modified defined contribution pension plan, the sample employer must supplement the initial individual account value at once. Employees with longer past service years require more expenditure. Certainly, there is a time value for this compensation. In this paper, we just measure the present value of the required costs.

In hybrid pension plan, the compensation expenses only appear for the employees who need to be assisted. There is a measurable amount for employers. With this added amount, the monthly 8,000 pension benefits will be reached. In order to compare these two plans' compensation expenses, they are both measured by the use of present value and completed in the model.

The detailed results are summarized in Table 8 .

According to the results, there is no doubt that more expenses make more benefits. As the average replacement
TABLE 8: Present value of compensation expenses.

\begin{tabular}{lccccc}
\hline ID Gender & $\begin{array}{c}\text { Present } \\
\text { age }\end{array}$ & $\begin{array}{c}\text { Entry } \\
\text { age }\end{array}$ & $\begin{array}{c}\text { Cost for } \\
\text { modified } \\
\text { defined } \\
\text { contribution } \\
\text { plan }\end{array}$ & $\begin{array}{c}\text { Cost for } \\
\text { hybrid } \\
\text { plan }\end{array}$ \\
\hline 1 & F & 54 & 46 & $342,531.00$ & $1,409,256.00$ \\
2 & M & 47 & 45 & $99,636.00$ & $192,012.00$ \\
3 & M & 46 & 32 & $1,569,581.00$ & 0.00 \\
4 & M & 44 & 32 & $571,364.00$ & $215,232.00$ \\
5 & F & 42 & 34 & $312,432.00$ & $746,028.00$ \\
6 & F & 46 & 38 & $269,894.00$ & $1,074,372.00$ \\
7 & M & 40 & 31 & $536,557.00$ & 0.00 \\
8 & F & 36 & 26 & $246,680.00$ & $683,952.00$ \\
9 & M & 40 & 28 & $544,157.00$ & 0.00 \\
10 & F & 50 & 36 & $121,106.00$ & $1,416,276.00$ \\
11 & M & 44 & 37 & $279,672.00$ & $258,828.00$ \\
12 & F & 50 & 32 & $157,799.00$ & $1,419,936.00$ \\
13 & F & 37 & 30 & $279,672.00$ & $233,820.00$ \\
14 & M & 49 & 39 & $411,674.00$ & $704,244.00$ \\
15 & F & 47 & 30 & $532,804.00$ & $1,222,500.00$ \\
\hline & & Total cost & & $6,275,559.00$ & $9,576,456.00$ \\
\hline
\end{tabular}

Resource: model calculation results.

ratio of hybrid plan increases more, the estimated compensation expenses for employer are much larger.

4.4. Risk Analysis. Every retirement pension plan presents several risks and the design of each plan determines how the risks are divided between employers and employees. Employers have the main responsibility on defined contribution plans.

One obvious risk is investment return. If the asset earns more than expected, the employee under this risk is happier. If the asset earns less, there may be a loss of benefits. In a word, the ultimate accumulated accounts depend on investment earnings to some degree. Investment returns help provide for promised benefits. Everyone expects to have an account which is overperformed. This risk is predominant in the actual operation.

Another risk is inflation rate. In this paper, we regard inflation as one component of investment return. The investment return will provide some protection. The inflation depreciates the value of future accumulated accounts.

The next risk is longevity. In this paper, we assume that the future pension benefits will be paid until death. Regardless of the possibility of ignoring this risk, it is traditionally considered that a defined benefit plan puts this risk on the employers and a defined contribution plan puts this risk on the employees. In our opinion, this conclusion is reasonable as a defined benefit plan/hybrid plan guarantees a promised benefit.

Finally, the salary increase risk is considered. The salary at retirement age is a predominant factor which needs to be monitored. If the salary is relatively higher than 
TABLE 9: Results of sensitivity analysis (replacement ratio).

\begin{tabular}{lcccc}
\hline $\begin{array}{l}\text { Tested } \\
\text { parameter }\end{array}$ & Changes & $\begin{array}{c}\text { Original } \\
\text { defined } \\
\text { contribution }\end{array}$ & $\begin{array}{c}\text { Modified } \\
\text { defined } \\
\text { contribution }\end{array}$ & Hybrid plan \\
\hline $\begin{array}{l}\text { Investment } \\
\text { return }\end{array}$ & $(+1 \%)$ & $0.55 \%$ & $1.45 \%$ & $0.21 \%$ \\
\hline Salary & $(+1 \%)$ & $-0.50 \%$ & $-1.29 \%$ & $-0.19 \%$ \\
increase & $(-1 \%)$ & $-0.50 \%$ & $-1.27 \%$ & $-1.89 \%$ \\
\hline
\end{tabular}

Resource: model calculation results.

expected, there is more pressure and more contributions for the certain pension plan. The final influence is uncertain. In the assumption, the salary increase rate is predicted based on the future service years.

4.5. Sensitivity Analysis. In order to measure the potential risks for several retirement pension plans, the following sensitivity analysis is completed. As we assume that the pension benefits will be paid until death, longevity risk is not considered in this part. The results are summarized in Table 9.

Based on the results in Table 9, it is evident that the employees are under some risks when the investment return rate declines by $1 \%$ annually. If the inflation rate increases by $1 \%$ annually, it will have a similar impact on the replacement ratios. The investment return risk of hybrid plan is not as severe as the other two pension plans. The modified defined contribution pension plan will be influenced most. This result is easy to understand, in a modified defined contribution pension plan, and the time value of the initial individual account at retirement age is the core of this plan.

The salary at retirement age will have a direct influence on the replacement ratio. The hybrid pension plan is most sensitive to this risk. Most employees have a fixed monthly pension benefit of 8,000 in this plan; the change of the denominator of replacement ratio is much more important. The modified defined contribution pension plan is still influenced by this risk. When the salary increases faster, the accumulated individual account, and thus estimated pension benefit, will be greater.

In conclusion, though the two improved pension plans will get a better result of replacement ratios, the potential risks will increase to some degree. The modified defined contribution pension plan is sensitive to both of the risk parameters. The hybrid pension plan is more sensitive to salary increase rate. When it comes to our traditional defined contribution pension plan, it is the steadiest one, with less fluctuation. As a result, both of the risks need to be monitored.

\section{Forecast}

In order to forecast the pension replacement ratio, we simplify defined contribution pension plan. The important parameters are kept retained, including investment income rate/interest rate $(i)$, pension benefit $(B)$, contribution rate $(c)$, contribution years $(n)$, pension paid years $(m)$, present salary, $(S)$ and salary increase rate $(g)$, as in [4].
Based on the parameters listed above, we can get the accumulated individual account. We assume that the contribution is made at the end of years and investment income rate is not equal to salary increase rate.

$$
\begin{aligned}
& \text { Account }= c S(1+g)(1+i)^{n-1} \\
&+c S(1+g)^{2}(1+i)^{n-2}+\cdots+c S(1+g)^{n} \\
&= \frac{c S(1+g)\left[(1+i)^{n}-(1+g)^{n}\right]}{i-g}, \\
& \text { Account }=B \frac{1-1 /(1+i)^{m}}{i} .
\end{aligned}
$$

According to the formula (1), the formula of $B$ is obtained.

So,

$$
B=\frac{c i S(1+g)(1+i)^{m}\left[(1+i)^{n}-(1+g)^{n}\right]}{(i-g)\left[(1+i)^{m}-1\right]} .
$$

Finally, the replacement ratio

$$
\mathrm{RR}=\frac{B}{S(1+g)^{n}}=\frac{c i(1+g)(1+i)^{m}\left[(1+i)^{n} /(1+g)^{n}-1\right]}{(i-g)\left[(1+i)^{m}-1\right]}
$$

According to the sample data, employee 7 is chosen for example. The future service year is 20 years, $n=20$. The fixed contribution rate is $10 \%, c=10 \%$. The salary increase rate is $5 \%, g=5 \%$. According to the life table and China pension market, we assume that m equals 18.77 years. Up to now, we find a basic formula relationship between investment return rate $(i)$ and pension replacement ratio. As the investment return rate changes, the replacement ratio will change.

In order to forecast the replacement ratio, Table 10 is shown.

It is obvious that the replacement ratio increases as the interest rate and certainly investment return increase. With the method of econometrics, linear regression, the relation between them is presented by "Eviews 5.0". To minimize the expected error as much as possible, we vary the form of interest rate, using quadratic and cube interest rate as explaining variables. The biquadrate interest rate is not significant, which is discarded.

Regression Formula:

$\mathrm{RR}=0.050925+2.388865 i-11.97265 i^{2}+216.2676 i^{3}+\varepsilon$

Std.Error:

$$
\begin{array}{llll}
(0.006067) & (0.277030) & (3.748962) & (15.51312)
\end{array}
$$

$t$-Statistic:

$$
(8.393567) \quad(8.623115) \quad(-3.19259)
$$

Prob:

$$
\begin{array}{llll}
(0.0002) \quad(0.0001) & (0.0188) & (0.0000)
\end{array}
$$

R-Squared: 0.999971. 
TABLE 10: Forecast relationship (partial).

\begin{tabular}{|c|c|c|c|c|c|c|c|c|c|c|}
\hline Interest rate $(i)$ & $3 \%$ & $4 \%$ & $6 \%$ & $7 \%$ & $8 \%$ & $9 \%$ & $10 \%$ & $11 \%$ & $12 \%$ & $13 \%$ \\
\hline Replacement ratio (RR) & $11.81 \%$ & $14.04 \%$ & $19.77 \%$ & $23.43 \%$ & $27.73 \%$ & $32.45 \%$ & $38.71 \%$ & $45.69 \%$ & $53.86 \%$ & $63.44 \%$ \\
\hline
\end{tabular}

Resource: model calculation results.

TABLE 11: Investment returns rate.

\begin{tabular}{|c|c|c|c|c|c|c|}
\hline Year & 2007 & 2008 & 2009 & 2010 & 2011 & 2012 \\
\hline Asset & $8.86 B$ & $35.572 B$ & $132.795 B$ & $227.158 B$ & $326.579 B$ & $401.98 B$ \\
\hline Investment rate & $7.66 \%$ & $2.6 \%$ & $4.36 \%$ & $2.85 \%$ & $2.53 \%$ & $5.68 \%$ \\
\hline
\end{tabular}

Resource: the national enterprise annuity fund business data in 2012, Human resources social security fund supervision, 2013.4.

It is clear that the regression formula fits this relationship well. Under the condition that the other factors are unchanged, with the improvement of investment return, the growth of enterprise annuity replacement rate is more significantly higher than the growth of investment return.

Certainly, the improvement of defined contribution pension plan design will increase the replacement ratio. If we devote ourselves to increasing the investment return rate, the replacement ratio will increase too. According to the corresponding linear regression relationship analysis, if the enterprise annuity replacement ratio level is about $25 \%$, the annual investment yields need to exceed 7\%.

The investment structure in China is not well developed now. If we want to have a better investment return, some limits must be cancelled. The investment income rate is around $6 \%$, which will result in a replacement ratio of $20 \%$.

In Table 11 there are the historical investment returns in China. The investment return is not satisfying during recent years. In a word, it is significant for us to think how to increase investment benefits as well as guarantee the security.

In the analysis, we just assume that $5 \%$ is the investment return rate. The actuarial assumption is used in the calculations, but it will never exactly reflect the plan's experience this year. The difference between actual and assumed experience creates actuarial gains and losses. A gain means the actual experience was more favorable, and less costly, than assumed. A loss means the opposite. If we want to forecast the future replacement ratio, it is important to get reasonable interest rate estimation which is discussed in [5].

\section{Conclusions and Recommendations}

The traditional defined contribution plan cannot satisfy the employees' demand, with shorter time to accumulate pension accounts. The initial amounts are not enough. According to the results of two improved plans proposed, modified defined contribution plan and the hybrid plan, both the replacement ratios become improved. The modified defined contribution pension plan considers the past service years of each employee while the hybrid pension plan presents the feature of defined benefit plan and guarantees a fixed pension benefit. The effectiveness of the latter one is better. The two improved defined contribution plans both mean a huge expenditure to employer. In particular, the cost of hybrid pension plan is much larger. In addition, the potential risks for retirement plans are analyzed, investment return, inflation rate, longevity risk rate, and salary increase rate. The relationship between investment return and replacement ratio is clear. If the investment return can be raised under a secure method, the pension market will have a great improvement as discussed in [6]. Much more consideration about the pension accumulated accounts investment strategy is necessary.

\section{Conflict of Interests}

The authors declare that there is no conflict of interests regarding the publication of this paper.

\section{Acknowledgments}

The authors thank the referee and the associate editor for their very useful suggestions and detailed comments. This paper is supported by the Fundamental Research Funds for the Central University in UIBE (13QNLG01).

\section{References}

[1] G. E. Rejda, Social Insurance and Economic Security, Prentice Hall, Upper Saddle River, NJ, USA, 1999.

[2] Ippolito and A. Richard, "Pension terminations for reversion," Journal of Pension Planning and Compliance, vol. 12, no. 3, pp. 221-422, 1986.

[3] C. Bellis and R. Lyon, Understanding Actuarial Management: The Actuarial Control Cycle, Society of Actuary, 2003.

[4] Y. Weili and N. Xiao, "The Relationship between Enterprise Annuity Fund Investment Rate and Replacement Ratio," Taiping Pension Company, LTD. Liaoning Branch.

[5] D. Dufresne, "Stability of pension systems when rates of return are random," Insurance Mathematics and Economics, vol. 8, no. 1, pp. 71-76, 1989.

[6] H. Yaodong, "The choice of the mode of the supplemental pension plans in China," Journal of Chongqing Business School, no. 3 , pp. 50-52, 2002. 


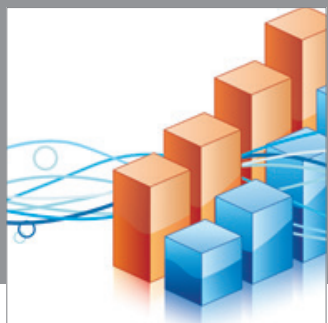

Advances in

Operations Research

mansans

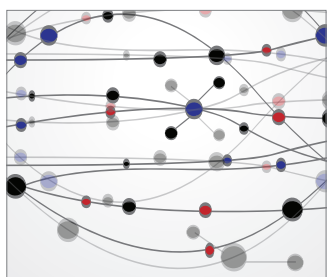

The Scientific World Journal
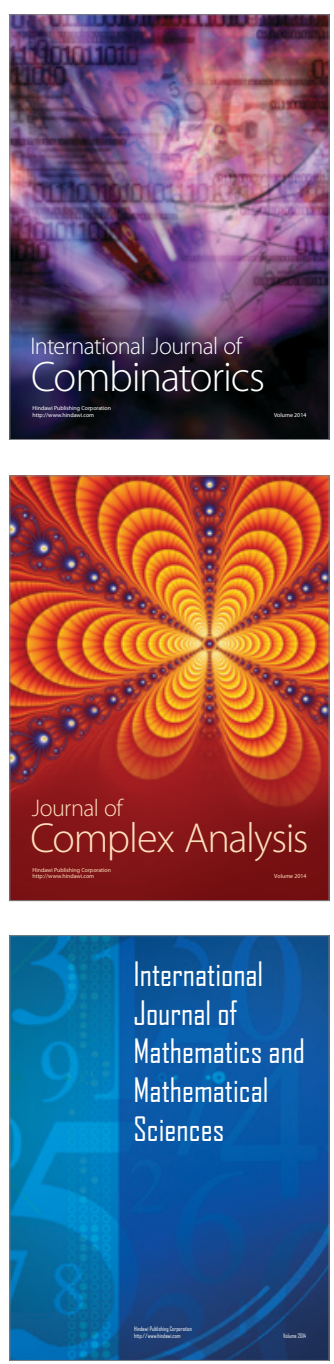
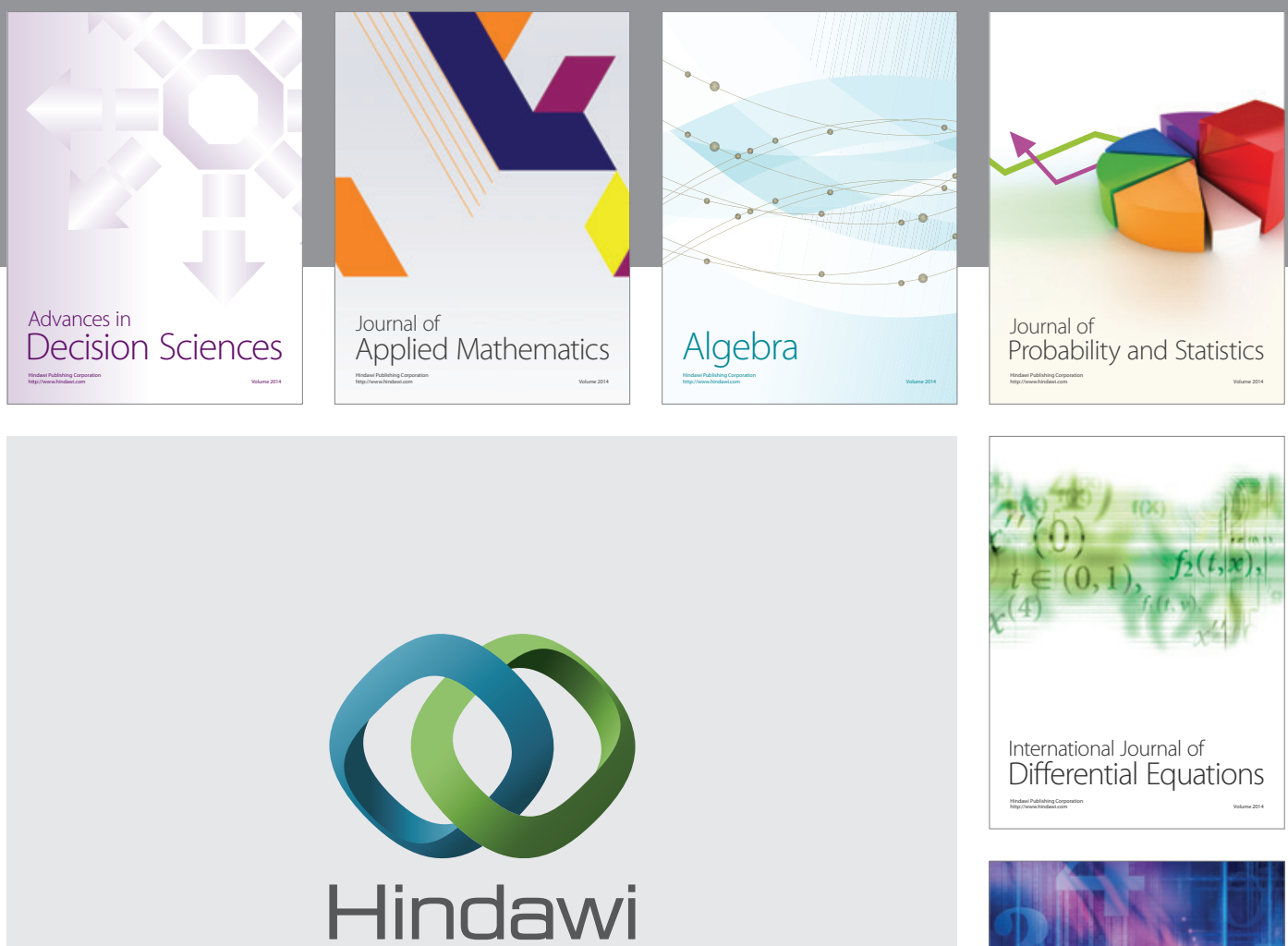

Submit your manuscripts at http://www.hindawi.com
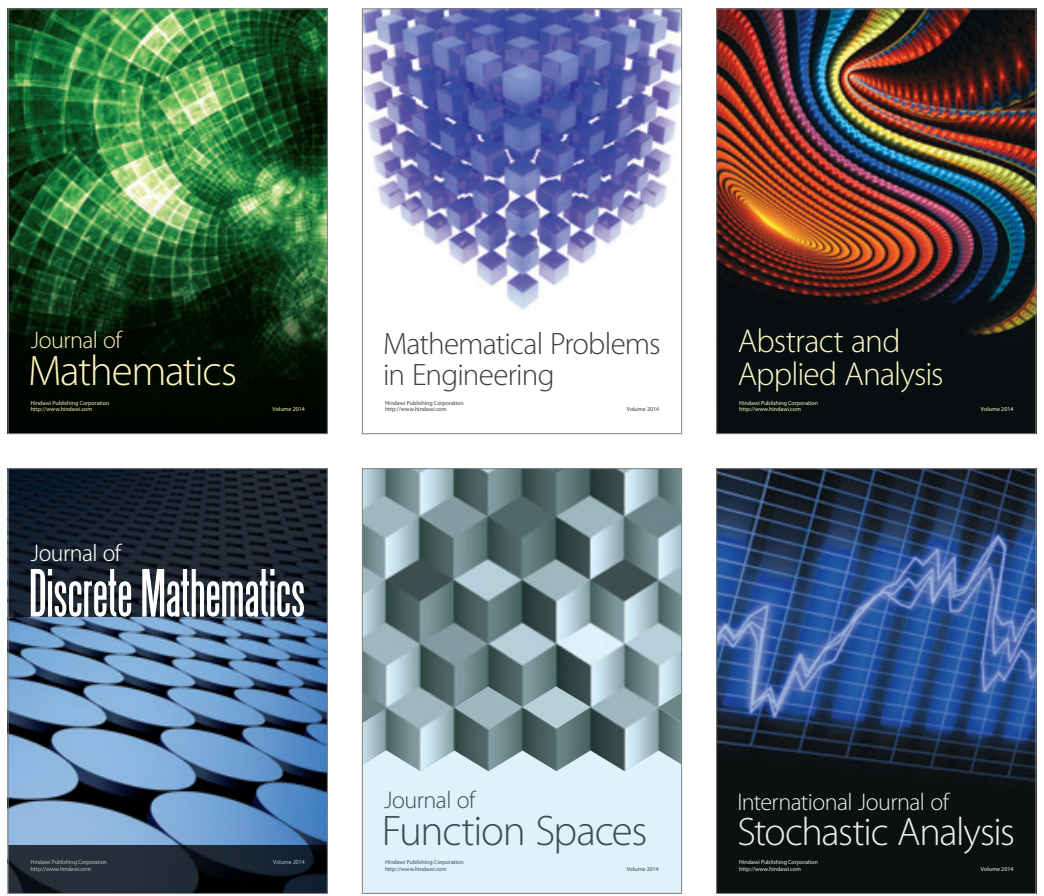

Journal of

Function Spaces

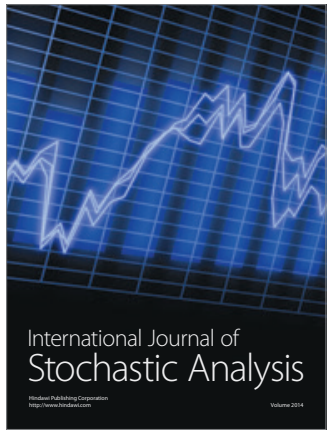

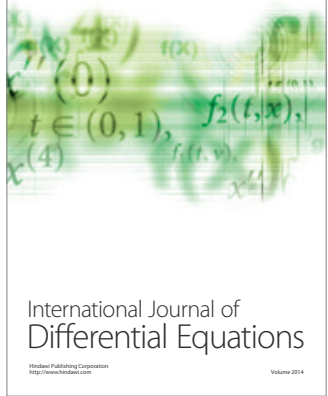
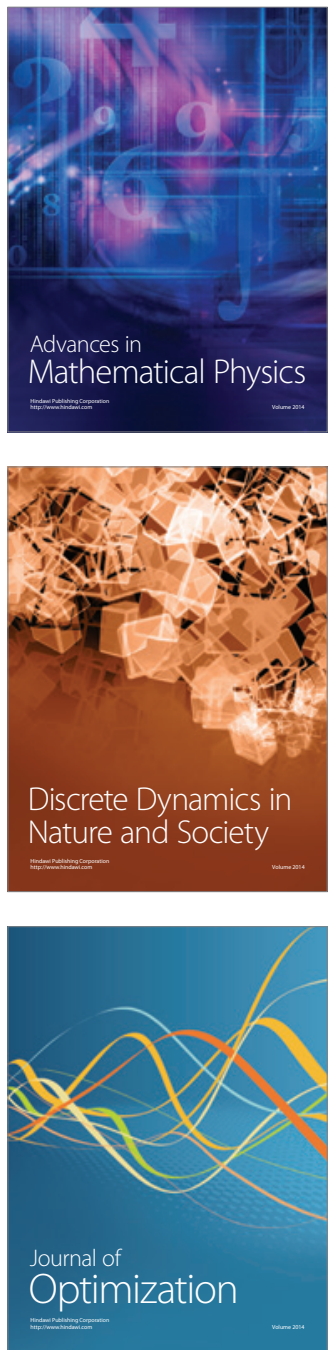